\title{
A comparison of the $N$-terminal sequence of the corresponding hemoglobin component between closely related chironomid species, Polypedilum nubeculosum and P. nubifer
}

\author{
Koichiro KAWAI ${ }^{1)}$, Satomi Hayashi ${ }^{2)}$ and Hiromichi ImABayASHI ${ }^{1)}$ \\ 1) Laboratory of Ecology, Faculty of Applied Biological Science, Hiroshima University, \\ Kagamiyama 1-4-4, Higashihiroshima, 739-8528 Japan \\ 2) Zeneka Pharmaceuticals Co., Ltd., Oyodonaka 1-1-88, Kita-ku, Osaka, 531-0076 Japan
}

(Received: 8 December 1998; Accepted: 8 June 1999)

Key words: chironomid larvae, hemoglobin, $N$-terminal sequence, Polypedilum

\begin{abstract}
A monomeric hemoglobin ( $\mathrm{Hb}$ ) component (MV) of a chironomid species, Polypedilum nubeculosum (PNc), was isolated, determined for its $N$-terminal amino acid sequence, and the sequence was compared with that of the corresponding $\mathrm{Hb} \mathrm{MV}$ of a related species, $P$. nubifer (PNf). In an alignment of 22 residues, only 5 positions were conserved. Replacements between hydrophobic and hydrophobic amino acids were observed at 5 positions whereas those between hydrophilic and hydrophilic amino acids were observed at 9 positions. In contrast, at only two positions, hydrophobic to hydrophilic replacements were observed. These results suggest a high speed of molecular evolution for the fifth monomeric $\mathrm{Hb}$ component of the genus Polypedilum.
\end{abstract}

\section{INTRODUCTION}

Chironomid larvae are a major component of freshwater benthic communities. Some subfamilies, such as Chironominae and Tanypodinae often living in oxygenpoor environments, are apparently of red hue at larval stages and have a more or less large amount of hemoglobins (Hbs) (Cranston, 1988). In contrast, other subfamilies, such as Diamesinae and Orthocladiinae mainly living in oxygen-rich environments, are apparently of whitish, greenish or purplish hue at larval stages, and usually do not possess any Hbs (Cranston, 1988). These Hbs play an important role in procuring sufficient amount of dissolved oxygen from oxygen-poor environments by virtue of their property of high affinity for oxygen and the low Bohr effect (Cranston, 1995). It has been reported that some Hbs cause severe type I allergic symptoms to human, and their amino acid sequences (Goodman et al., 1983) and the DNA sequences (Antoine and Niessing, 1984) have been studied. A European species, Chironomus thummi thummi, has a total of 12 dimeric or monomeric $\mathrm{Hb}$ components, and the homology of a component to another one in terms of amino acid sequence has been reported to be in a range of 16-48\% (Baur et al., 1982). However, there have been no reports on comparisons of the $\mathrm{N}$-terminal sequence and the whole sequence of the homologous or corresponding $\mathrm{Hb}$ components among related chironomid species.

In our previous studies, a monomeric $\mathrm{Hb}$ component (MV) of a species distributed worldwide, Polypedilum nubifer (PNf), was purified from larvae and proven to be a potent allergen for human (Kawai et al., 1996); thereafter, its gene was cloned and the whole amino acid sequence was estimated (Kawai and Muraguchi, 1998). 
In this study, the chromatographically corresponding $\mathrm{Hb} \mathrm{MV}$ to PNf-MV was purified from another species of the genus Polypedilum, $P$. nubeculosum (PNc), and its $N$-terminal sequence was determined. Based on a comparison of the $N$-terminal sequence between the two $\mathrm{Hb}$ components, PNf-MV and PNc-MV, the difference was discussed in terms of $\mathrm{Hb}$ function and molecular evolution.

\section{Materials And Methods}

\section{Chironomid larvae}

Larvae of PNc were obtained by laboratory culture. In brief, numerous female adults, attracted to the lights emitted by vending machines, were collected along the Kurose and Nuta Rivers of Hiroshima Prefecture, Japan, in May to October 1995. Newly-hatched larvae from egg masses laid by the females, were reared in containers $(\phi 30 \mathrm{~cm} \times \mathrm{H} 15 \mathrm{~cm})$, which were spread with fine sand to a depth of $1.5 \mathrm{~cm}$, filled with dechlorinated water to a $10-\mathrm{cm}$ level and aerated through an airstone. They were fed initially with milk (Morinaga 3.5, Morinaga Nyugyo Co., Ltd., Tokyo, Japan) and thereafter with pulverized Nishikigoi food (Hikari, large pellet, Kyorin Food Ind., Ltd., Himeji, Japan). Emerging adults were liberated into a cage (W60 $\mathrm{cm} \times \mathrm{D} 40 \mathrm{~cm} \times \mathrm{H} 135 \mathrm{~cm}$ ), and fertilized egg masses were obtained in the cage. Luminous condition was as follows: dusk (2 h)-day (10 h)-dawn (4 h)-night (8 h). Intensity of illumination was $600 \mathrm{~lx}$ and $71 \mathrm{x}$ at the point $20 \mathrm{~cm}$ beneath the ceiling at the center of the cage at day and at dusk/dawn, respectively. The last instar larvae were collected and stored at $-80^{\circ} \mathrm{C}$ until analysis.

\section{Purification of monomeric $\mathrm{Hb}(\mathrm{s})$}

Purification of monomeric $\mathrm{Hb}(\mathrm{s})$ was performed according to the methods described by Kawai et al. (1996). Total monomeric $\mathrm{Hb}$ was purified from crude larval extract by gel filtration using a Sephadex G-75 (superfine) column (Amersham
Pharmacia Biotech Inc., Uppsala, Sweden). A monomeric $\mathrm{Hb}$ component $\mathrm{MV}$, corresponding to PNf-MV, was separated by anion exchange chromatography on a DEAE Sephadex A-50 column (Amersham Pharmacia Biotech Inc.).

\section{$S D S-P A G E$}

SDS-PAGE was usually performed on the basis of Laemmli (1970). Samples were mixed with a sample buffer containing $5 \%$ 2-mercaptoethanol, boiled, and electrophoresed at $30 \mathrm{~mA}$ for $4 \mathrm{hrs}$. The gel plate was composed of a stacking gel (4\% acrylamide in $0.125 \mathrm{M}$ Tris- $\mathrm{Cl}, \mathrm{pH}$ 6.5) and a separation gel $(17.5 \%$ acrylamide in $0.375 \mathrm{M}$ Tris-Cl, pH 8.8). After running, the gel was stained with Coomassie brilliant blue R250.

\section{Determination of $\mathrm{N}$-terminal residues}

$N$-terminal residues were determined by automatic Edman degradation with a protein sequencer Model PSQ-1 (SHIMADZU RIKAKIKAI, Tokyo, Japan).

\section{Results}

Purification of monomeric Hbs from $P N C$ larvae

Monomeric $\mathrm{Hbs}$ of PNc larvae were purified by gel filtration of crude extract on a Sephadex G-75 column and fractionated on a DEAE Sephadex A-50 column. At least six peaks were revealed and designated as MI-MVI according to the elution order (Fig. 1). The second peak (MII) was predominant in contrast to PNf (Kawai et al., 1996), for which the sixth peak (MVI) was predominant. The fifth peak of $\mathrm{PNc}$ (PNc-MV), corresponding to the fifth one of PNf (PNf-MV) in the elution order and in $\mathrm{KCl}$ concentration at the elution peak, was pooled and further purified by successive rechromatography using a DEAE Sephadex A-50 column and a Sephadex G-75 column. The purity of the isolated PNc-MV and its similarity to PNf$\mathrm{MV}$ in molecular weight was confirmed by SDS-PAGE (Fig. 2). 

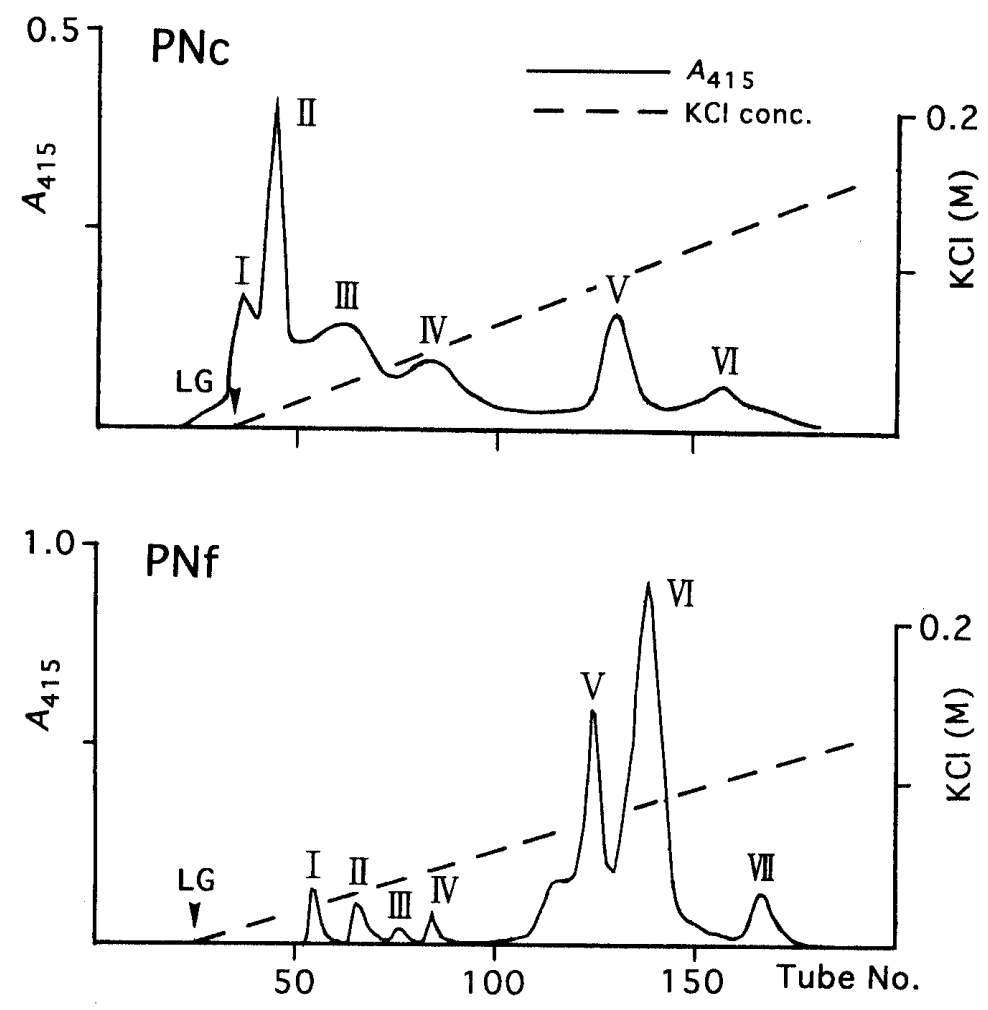

Fig. 1. Elution patterns of monomeric Hbs of Polypedilum nubeculosum (PNc) and P. nubifer (PNf) in anion exchange chromatography. A linear concentration gradient of $\mathrm{KCl}$ in the buffer was applied at an arrow LG. The pattern for PNf was cited from Kawai et al., 1996.

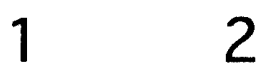

$66 \mathrm{kDa}$

$42 \mathrm{kDa} \rightarrow$

$30 \mathrm{kDa}$

\section{$17 \mathrm{kDa} \rightarrow$}

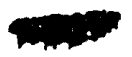

Fig. 2. MV profiles of PNc and PNf separated by SDS-PAGE. Lane 1, PNc-MV; lane 2, PNfMV.

Determination of N-terminal sequence of $P N C-M V$

The $N$-terminal amino acid sequence of
PNc-MV was determined down to position 22 (Fig. 3). Glycine, serine and threonine were rich, while alanine, arginine, asparagine, cysteine, glutamine, histidine, methionine and phenylalanine were lacking in the sequence.

Comparison of N-terminal sequences between PNc-MV and PNf-MV

The $N$-terminal sequence of PNc-MV was aligned with that of PNf-MV in 22 amino acid length. On the basis of Kawai and Muraguchi (1998), positions 1-4, 5-20, 21 and 22 were estimated to construct $N A$, $A$-helix, $A B$-bend and $B$-helix, respectively. Only five positions in a 22 -alignment were conserved (23\% in homology). A replacement between hydrophobic and hydrophobic amino acid was observed at five positions, while that between hydrophilic and hydrophilic amino acid was observed at nine positions. A replacement between hydrophilic and hydrophobic amino acid was observed only at two positions. 


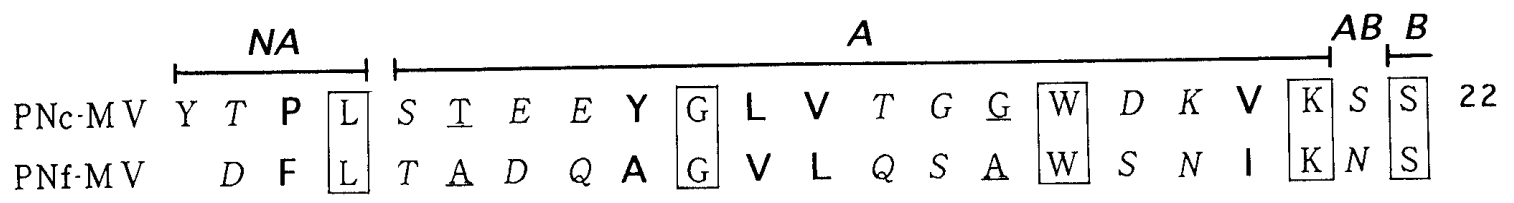

Fig. 3. Comparison of $N$-terminal amino acid sequences between PNc-MV and PNf-MV. $A$ and $B$ show $2 \alpha$-helix portions of globin, and $N A$ and $A B$ show 2 non-helical portions, i.e., a $N$-terminal portion and a bend portion between $A$-helix and $B$-helix, respectively. Conserved positions are indicated in boxes. Italics, Gothics and underlined characters indicate the replacements of hydrophilic to hydrophilic, hydrophobic to hydrophobic and hydrophilic to hydrophobic, respectively.

\section{Discussion}

Chironomid larvae of all the species belonging to the subfamilies Tanypodinae and Chironominae, and some species belonging to the subfamily Orthocladiinae are known to have a more or less large amount of cell-free Hbs in their body fluid (Cranston, 1988). These Hbs are considered to be essential to survive in such water environments that sometimes incur deficiency of dissolved oxygen. Nevertheless, only a few studies have been undertaken on amino acid and genetic analysis for these Hbs, but comparisons of the corresponding Hbs between the related chironomid species have not previously been performed.

In this study, a monomeric $\mathrm{Hb}$ component MV of a species distributed worldwide, $P$. nubeculosum, was purified, and its $N$-terminal amino acid sequence was determined. The $N$-terminal sequence was compared with that of an already reported similar monomeric $\mathrm{Hb} \mathrm{MV}$ of another Polypedilum species, $P$. nubifer (Kawai et al., 1996), and the homology between these two MVs was proven to be very low. This suggests a high molecular evolution speed of the fifth monomeric Hb component of these chironomid species.

The amino acid analysis demonstrated that only 5 in $22 \mathrm{~N}$-terminal residues, positions $4,10,16,20$ and 22 , were conserved in the alignments of both PNc-MV and PNf-MV. These positions were considered to be essential for exertion of the $\mathrm{Hb}$ function. Among these residues, tryptophan at position 16, i.e., A12 (position 12 of $A$ - helix), was estimated to be a semi-invariant position and to construct $\mathrm{A} / \mathrm{E}$ contact (Goodman et al., 1983). In contrast, A2, where a hydrophobic to hydrophilic replacement occurred, was considered not to be involved in the $\mathrm{Hb}$ function. On the other hand, other positions, where only hydrophilic to hydrophilic or hydrophobic to hydrophobic replacements occurred, were considered to be more or less important in exerting the $\mathrm{Hb}$ function in some way. For example, A5 was estimated to construct A/Eh contact (Goodman et al., 1983). Additional 4 positions, NA3 (position 3 of $N A$ ), A7, A 8 and A15, where hydrophobic to hydrophobic replacements occurred, were also possibly involved in haem pocket construction, because a haem pocket should be constructed exclusively by hydrophobic amino acids (Perutz et al., 1960).

Strong allergenic cross-reactivity between PNf-MV and PNc-MV has been suggested (Kawai and Sakamoto, 1992). That is, murine $\operatorname{IgE}$ antibodies raised against PNf-MV strongly binded to PNc-MV. This means that there are only small conformational differences between these Hbs in spite of the remarkable differences in $N$ terminal sequences, because IgE epitopes on chironomid Hbs are situated within the sequences comprising the surface-exposed or bend portion and with high flexibility (Baur et al., 1982, 1986). This may be the reason why such an amino acid replacement that does not change the polarity of the position hardly causes conformational changes.

Some Hbs of a European species, $C$. thummi thummi, have been estimated to be 
derived from a common ancestral $\mathrm{Hb}$ to insects and annelids about 600 million years ago, still before the time of the branch (about 470 million years ago) for vertebrate hemoglobins and myoglobins in the globin genealogical tree (Goodman et al., 1975). In this study, on the other hand, PNc-MV was estimated to be the corresponding $\mathrm{Hb}$ component to PNf-MV on the basis of the elution order and $\mathrm{KCl}$ concentration at the elution peak on anion exchange chromatography and of SDSPAGE analysis. However, it may be confirmed only by detection of a common gene locus coding for these two $\mathrm{Hb}$ molecules whether these Hbs are exactly homologous, i.e., whether these had been derived from a common ancestral monomeric $\mathrm{Hb}$, or not. Further examinations of amino acid sequences of homologous Hbs to distantly related chironomid species may lead to elucidation of relationships between the evolutional processes of chironomids and those of their Hbs.

\section{REFERENCE}

Antoine, M. and J. Niessing (1984) Intron-less globin genes in the insect Chironomus thummi thummi. Nature, 30: 795-798.

Baur, X., H. Aschaur, G. Mazur, M. Dewair, H. Prelicz, and W. Steigemann (1986) Structure, antigenic determinants of some clinically important insect allergens: Chironomid hemoglobins. Science, 233: 351-354.

Baur, X., M. Dewair, G. Fruhmann, H. Aschaur, J. Pfletschinger and G. Braunitzer (1982) Hypersensitivity to chironomids (non-biting midges): localization of the antigenic determinants within certain polypeptide sequences of hemoglobins (erythrocruorins) of Chironomus thummi thummi (Diptera). J. Allergy Clin. Immunol., 69: 66-76.

Cranston, P. S. (1988) Allergens of non-biting midges (Diptera: Chironomidae): a systematic survey of chironomid haemoglobins. Med. Veter. Entomol., 2: 117-127.

Cranston, P. S. (1995) Physiological diversity. In: The Chironomidae. The Biology and Ecology of Non-biting Midges (eds., Armitage, P., P. S. Cranston, and L. C. V. Pinder) pp. 4-5, Chapman \& Hall, London.

Goodman, M., G. Braunitzer, T. Kleinschmidt and H. Aschauer (1983) The analysis of a protein-poly- morphism. Evolution of monomeric and homodimeric haemoglobins (erythrocruorins) of Chironomus thummi thummi (Insecta, Diptera). HoppeSeyler's Z. Physiol. Chem., 364: 205-217.

Goodman, M., G. W. Moore and G. Matsuda (1975) Darwinian evolution in the genealogy of haemoglobin. Nature, 253: 603-608.

Kawai, K. and A. Muraguchi (1998) Gene cloning of a monomeric hemoglobin of a widely distributed chironomid Polypedilum nubifer. Hydrobiologia, 368: 91-99.

Kawai, K. and K. Sakamoto (1992) Cross-reactivities of murine IgE-inducing larval hemoglobins among various chironomid species. Jpn. J. Sanit. Zool., 43: 95-103.

Kawai, K., H. Tagoh, K. Yoshizaki, G. Murakami and A. Muraguchi (1996) Purification and characterization of an allergenic monomeric hemoglobin from a chironomid distributed worldwide, Polypedilum nubifer. Int. Arch. Allergy Immunol., 110: 288-297.

Laemmli, U. K. (1970) Cleavage of structural proteins during the assembly of the head of bacteriophage T4. Nature, 227: 680-685.

Perutz, M. F., M. G. Rossmann, A. F. Cullis, H. Muirhead, G. Will and A. C. T. North (1960) Structure of haemoglobin. A three-dimensional fourier synthesis at 5.5 - $\AA$. resolution, obtained by X-ray analysis. Nature, 185: 416-422.

\section{摘要}

近縁ユスリカ 2 種, Polypedilum nubeculosum 之 P. nubifer の対応へモグロビン成分の $\mathrm{N}$ 末端アミノ酸配列の比較 河合幸一郎1) 林 里 実 ${ }^{2)}$ 今林博 道 ${ }^{11}$

1) 広島大学生物生産学部動物生態学研究室

（テ739-8528 東広島市鏡山 1-4-4） 2) ゼネ力薬品株式会社

（テ531-0076 大阪市北区大淀中 1-1-88）

ユスリカの一種, Polypedilum nubeculosum (PNc) か らモノマーヘモグロビン $(\mathrm{Hb})$ 成分 $\mathrm{MV}$ を単離し，その $\mathrm{N}$ 末端アミノ酸配列を決定した。これを近縁種，P.nubifer (PNf) の対応成分 MV と比較したところ，22 残基の うち完全に保存されていたのは 5 残基のみであり，非常 に相同性が低いことがわかった。 しかし，置換がみられ る 16 残基のうち，親水性了ミ/酸-柾水性了ミノ酸間の 置換はわずか 2 残基のみであり，他は全て親水性-親水 性あるいは㻋水性一蹯水性アミノ酸同士の置換であった。 これらの結果は, Polypedilum 属のモ/マー Hb 第 5 成 分の分子進化速度が極めて速いことを示唆している. 